\title{
DYSF wt Allele
}

National Cancer Institute

\section{Source}

National Cancer Institute. DYSF wt Allele. NCI Thesaurus. Code C94681.

Human DYSF wild-type allele is located in the vicinity of 2p13.3 and is approximately 233 $\mathrm{kb}$ in length. This allele, which encodes dysferlin protein, is involved in sarcolemmal repair and muscle contraction. Mutation of the gene is associated with limb girdle muscular dystrophy type 2B, distal myopathy with anterior tibial onset, and Miyoshi myopathy. 